\title{
4 Catholic Fundraising to Educate the Poor. The History of the Société Civile du Crédit de la Charité (1855-1878)*
}

The religious-philosophical dispute is known to be one of the classic zones of tension in Belgian society. Throughout the $19^{\text {th }}$ century, Catholics and liberals struggled for power and disputed control over the socialisation of the masses. This polarisation escalated between 1879 and 1884 in an ardent 'school war', with the 'soul of the child' at stake. ${ }^{1}$ By then both Catholics and liberals had invested in fundraising organisations in order to develop their preferred system of schooling. Associations such as the liberal Denier des Écoles (1872) or the Katholieke Schoolpenning ('Catholic School Penning', 1876) collected gifts from their sympathisers in order to found free Catholic and non-confessional schools. ${ }^{2}$ However, the mechanism of collecting funds to finance private education proj-

\footnotetext{
* I would like to thank Benoît de Meeûs d'Argenteuil for the many suggestions and additional references.

1 See: Jacques Lory, Libéralisme et instruction primaire 1842-1879. Introduction à l'étude de la lutte scolaire en Belgique (Université de Louvain. Recueil de travaux d'histoire et de philologie, $6^{\mathrm{e}}$ série, fascicule 17-18), 2 vol. (Leuven: Editions Nauwelaerts, 1979); Jeffrey Tyssens, Om de schone ziel van 't kind. Het onderwijsconflict als een breuklijn in de Belgische politiek (Bijdragen Museum van de Vlaamse Sociale Strijd, 15) (Ghent: s.n., 1998). See also: Paul Wynants with the cooperation of Martine Paret, "École et clivages aux XIXe et XXe siècles," in Histoire de l'enseignement en Belgique, ed. Dominique Grootaers (Brussels: CRISP, 1998), 13-84; Raf Vanderstraeten, "Cultural Values and Social Differentiation: The Catholic Pillar and its Education System in Belgium and the Netherlands," Compare 32, no 2 (2002): 133-148; Els Witte, "The Battle for Monasteries, Cemeteries and Schools: Belgium," in Culture Wars. Secular-Catholic Conflict in Nineteenth Century Europe, eds. Christopher Clark and Wolfram Kaiser (Cambridge: Cambridge University Press, 2003), 102-128; Raf Vanderstraeten, "Religious Congregations at Work in Education - with Special Reference to Belgium," in International Handbook of Catholic Education Challenges for School Systems in the 21st Century, eds. Gerald R. Grace and Joseph O'Keefe (Dordrecht: Springer Verlag, 2007), 519-539; Patrick Loobuyck and Leni Franken, "Religious Education in Belgium: Historical Overview and Current Debates," in Religious Education in a Plural, Secularised Society: A Paradigm Shift, eds. Leni Franken and Patrick Loobuyck (Münster/New York/München/Berlin: Waxmann, 2011), 35-55; Paul Wynants, Vincent Dujardin, Henk Byls and Sarah Van Ruyskensvelde, "Conflicten als vormgevers en stoorzenders. Ideologische breuklijnen en twee wereldoorlogen," in Katholiek onderwijs in België. Identiteiten in evolutie 19de -21ste eeuw, eds. Jan De Maeyer and Paul Wynants (Averbode: Halewijn, 2016), 79-106.

2 Eliane Gubin and Jean-Pierre Nandrin, “Het liberale en burgerlijke België, 1846-1878,” in Nieuwe Geschiedenis van België. I. 1830-1905 (Tielt: Lannoo, 2005), 308.
}

๑ OpenAccess. (c) 2019 Stijn Van de Perre, published by De Gruyter. (cc) BY-NC-ND This work is licensed under the Creative Commons Attribution-NonCommercial-NoDerivatives 4.0 License. https://doi.org/10.1515/9783110581546-004 
ects that was used in the 1870s was by no means entirely new. In this chapter, I will focus on a particular precursor. In 1855, the governor of the Société Générale, Count Ferdinand de Meeûs (1798-1861), founded the Société Civile du Crédit de la Charité ('Civil Company for Credit of Charity'). He introduced an original formula for raising capital to invest in Catholic schools for poor working class children. The society issued shares, without interest but which were refundable after a certain period. Its mission was to push back pauperism in industrial centres. I will answer various questions in relation to this insufficiently studied initiative. Did Ferdinand de Meeûs succeed in his aims? Why was his example not followed by similar initiatives? What was its involvement in the phase preceding the school war? Did this project matter anyway?

\section{Financing schools}

In both Belgian and international historiography, only limited research has been done on financing mechanisms for funding elementary schools and popular education in a broader sense. ${ }^{3}$ This can be explained by the rather limited availability of serial source material. Nevertheless, discussions on school financing are of major importance, as these debates concern the role private organisations and (local) authorities should play in education. The relation between private and public engagements often caused lively conflicts. ${ }^{4}$ Fundraising played a decisive role in the control over how education was organised and what the public was taught. In various countries the battle over the 'soul of the child', not in the least among the poor, inevitably translated ideological antagonisms into a critical political dispute. ${ }^{5}$ Recently, there has been some attention paid to the financing of education on the international academic forum. At a conference in 2011 on

\footnotetext{
3 Peter Heyrman, "Bedrijfscultuur van katholieke scholen. Financies en beheer," in Katholiek onderwijs in België, 296; Johannes Westberg, Funding the Rise of Mass Schooling. The Social, Economic and Cultural History of School Finance in Sweden, 1840-1900 (Cham: Palgrave Macmillan, 2017), 2.

4 See, for example: Harry Van Dyke, "Government schools or Free schools? Abraham Kuyper Addresses a Long-Standing Controversy in the Dutch Parliament," Canadian Journal of Netherlandic Studies 35, no. 2 (2014): 29-45.

5 See, for example, the controversies regarding the establishment of a private education network for the Catholic poor in Ireland: Kristin V. Brig, “'Torn from Their Mother's Breasts': The Battle for Impoverished Souls in Ireland, 1853-1885," Madison Historical Review 13 (2016): 27-34. For the debate on the role of Catholic schools in France since 1870, see: Sarah A. Curtis, "Supply and Demand: Religious Schooling in Nineteenth-Century France," History of Education Quarterly 39, no. 1 (1999): 51-72.
} 
the 'History of Schooling: Politics and Local Practice' at Uppsala University (Sweden), sessions were programmed on 'School Finance' and on the 'Economics of Education'. 6 Special issues of the Nordic Journal of Educational History (2015) and Paedagogica Historica (2016) presented an overview of the relevant historiography. ${ }^{7}$ All contributions emphasised the need for more systematic research in order to develop new insights into the massification of education, especially in relation to industrialisation and state building processes. ${ }^{8}$

Private organisations, both lay associations and religious congregations, faced several challenges in their ambition to finance Catholic schools. ${ }^{9}$ First, they had to find an appropriate venue. This venue could be temporarily placed at their disposal, granted to them on a permanent basis, or acquired with collected money or borrowed investment capital. If the latter was the case, the repayments resulted in a financial burden for years to come. Once the activities had taken off, the staff related and operational costs continued to inflict recurring expenses. When an institution did not make an appeal to government subsidies or logistical support ${ }^{10}$, it became dependant on philanthropy. Foundations ("libéralités”) or legacies offered a more definitive solution. Quite often these foundations consisted of both immovable property and cash funds. The benefactors often introduced conditions with regard to the allocation of the donation. Carefully managed and invested, these resources could provide a reliable source of income. To cover more current needs, associations held collections or organised benefit events. School board members went out to petition the local elite and other potential backers. A great many parish priests did not hesitate to cooperate in person. ${ }^{11}$ Finally, there were also some other opportunities to raise income.

6 The Swedish and Swiss contributions were included in the section 'School Finance: Funding and Regional Variations' in History of Schooling. Politics and Local Practice, eds. Carla Aubry and Johannes Westberg (Frankfurt am Main: Peter Lang, 2012).

7 See: Anne Berg, Samuel Edquist, Christin Mays, Johannes Westberg and Andreas Åkerlund, "The History of Educational Finance. Introduction," Nordic Journal of Educational History 2, no. 1 (2015): 3-22; Marcelo Caruso, "Why Do Finance? A Comment about Entanglements and Research in the History of Education. Concluding Remarks," Ibidem, 141-149; Carla Aubry Kradolfer and Michael Geiss, "The Backbone of Schooling: Entangled Histories of Funding and Educational Administration - Introduction,” Paedagogica Historica 52, no. 4 (2016): 315-324.

8 Westberg, Funding, 4. This is why Westberg argues for a "materialistic turn in the field of educational history".

9 Heyrman, "Bedrijfscultuur," 304-306.

10 In addition to financial support, a municipality could also provide for rooms, heating, furniture or school materials. For examples, see: Désiré P.A. De Haerne, Tableau de la charité chrétienne en Belgique (Brussels: C.J. Fonteyn, 1857), annexe I (comments on the institutions of the diocese Tournai).

11 Heyrman, "Bedrijfscultuur," 300-301. 
Recurrent costs could be covered by levying school fees from solvent pupils. Besides that, different religious orders developed lucrative secondary activities (such as lace schools, laundries, paid caregiving for elderly and disabled persons). These activities made it possible to fund their educational work. ${ }^{12}$

If private associations eventually succeeded in generating the necessary means through a certain capital, they faced yet another problem. Under French law (which was still valid), Belgian policymakers were not at all inclined to grant them legal personality, fearing the return of the old mortmain practices ("mainmorte"). This position meant that such organisations were unable to perform legal transactions. They merely existed as de facto associations. To bypass this problem, people started looking for all sorts of solutions. Besides working with straw men, the formation of a partnership or the setting up of a civil company ("société civile") also offered an answer. In both cases, the partnerships had no real legal status, but the partners or shareholders made an agreement by mutual consent on what was to happen when someone left or died. ${ }^{13}$ As from 1847 , successive liberal ministers of Justice attempted to reverse the existing practices of tolerance towards private (i.e. Catholic) organisations that received a foundation, donation, or bequest for charitable and educational purposes. ${ }^{14}$

12 Maarten Van Dijck and Kristien Suenens, "La Belgique charitable: Charity by Catholic Congregations in Rural West Flanders, 1830-1880," in Armenfürsorge und Wohltätigkeit. Ländliche Gesellschaften in Europa, 1850-1930. Poor Relief and Charity. Rural Societies in Europe, 18501930, eds. Inga Brandes and Katrin Marx-Jaskulski (Frankfurt am Main: Peter Lang, 2008), 169 -172; Heyrman, "Bedrijfscultuur,” 304-305.

13 Heyrman, "Bedrijfscultuur," 306 -307. See also: Joeri Vananroye, Morele wezens en wetsontduikende monniken. Over de vereniging zonder rechtspersoonlijkheid (Antwerp/Cambridge: Intersentia, 2012), 2-5; Edouard Haus, “Sociétés civiles - personnes morales," La Belgique Judiciaire, 13, no 3-4 (1855): 33-41; Fred Stevens, "Les associations religieuses en Belgique pendant le 19e siècle," in Religious Institutes in the 19th and 20th Centuries: Historiography, Research and Legal Position, eds. Jan De Maeyer, Sofie Leplae and Joachim Schmiedl (Leuven: University Press, 2004), 198-201.

14 Witte, “The Battle,” 110; Gubin and Nandrin, "Het liberale en burgerlijke België 1846-1878," 296-297. 


\section{Shares for a good cause}

"Let's start; We will do better later", was the tagline Count Ferdinand de Meeûs, his four oldest sons (Ferdinand François, Henri, Julien and Joseph ${ }^{15}$ ), and his son-in-law baron Joseph François de Roest d'Alkemade (1831-1892) ${ }^{16}$ used when they assembled, on 3 December 1855, in Saint-Josse-ten-Noode before notary Philippe Alexandre Coppyn (1796-1874). They came to pass the founding deed of an association they named the Société Civile du Crédit de la Charité. According to the statutes, this enterprise focused on the funding of Catholic schools for poor children of the working class, and on shelters for old and sick workers. ${ }^{17}$ The society concentrated on the industrial regions, especially those where there was coal mining, in the provinces of Hainaut and Liège, and on Brussels. The intention was to develop educational initiatives, preferably led by religious. Where possible, the Société was also willing to support or patronise other charitable organisations.

The Société Civile du Crédit de la Charité opted for a remarkably original formula to raise funds. Capital was collected by issuing two classes of shares. The base was laid by the foundation shares ("actions de fondation"), worth 500 Belgian francs (fr). Buyers renounced all interest or dividends. This investment was only to be released in case of liquidation of the society. Of these shares, the issue was limited to 500,000 fr. In addition, there were participation shares ("actions de participation"), also worth 500 fr. Buyers of this kind of shares could not count on dividends either, but they were promised an interest rate of 2.5 per cent. Buyers could choose for a refund of capital after a period of 20, 30 or 50 years. Furthermore, the company also accepted gifts. The statutes included clear directives on the procedures that should be followed. All means were to be invested on the stock market. This produced income from dividends which was subsequently used by the Société to fund its activities. The general rule dictated that with a capital of 500,000 fr, up to 60 per cent of the net income could

15 Ferdinand François Joseph Antoine (1825-1916), Henri Joseph Ferdinand (1826-1913), Jean Baptiste Joseph Ferdinand Julien (1827-1867) and Joseph François Ferdinand (1829-1910). See: Charles Poplimont, La Belgique héraldique, Vol. VII, -M (Paris: Walder, 1866), $240-241$ and the website of the Association Familiale d'Argenteuil (www.demeeus.org).

16 François de Roest d'Alkemade married on 20 April 1854 to Marie Louise Pauline Françoise de Meeûs (1831-1865). See Poplimont, La Belgique, 240.

17 The statutes were also published as a brochure: Société du Crédit de la charité (Brussels: Emm. Devroye, 1855). See also De Haerne Tableau, 84-85; A. Dufau, "Société civile du crédit de la charité en Belgique,” Annales de la charité 13 (1857): 218-220; Poplimont, La Belgique, 235-236. 
be spent on subsidies. In case of a capital between 500,000 to 1 million fr this part was raised to 75 per cent, and when the capital exceeded one million fr, the proportion increased to 90 per cent. This mechanism was designed to protect capital and commitments, and to ensure the proper functioning of the organisation in the long term. The issuance of shares was launched on January 1, 1856 and was, at least according to the Société itself, an instant success. ${ }^{18}$

Even King Leopold I (1790 - 1865) purchased several shares, and he explicitly welcomed the initiative. ${ }^{19}$ The shareholders were not only members of the wealthy upper class, but also directors, executives, and even ordinary employees of coalmines, factories and other industrial enterprises. Some people wished to remain anonymous. By the end of December 1855, 450,000 fr were collected already. Thanks to the increase in the value of the investments, the Société soon rounded the cape of 500,000 fr. This implied a margin available for subsidies of about 30,000 fr. In the course of 1856, the Société already supported more than 30 schools for poor children..$^{20}$ By 1861, this number grew to 67 institutions, in 1862 to 88 , in 1866 to 92 and in 1875 to $116 .^{21}$

\section{A top banker as inspirer}

The success of this imitative was no coincidence, as the driving force behind the Société was a figure of major importance: Count Ferdinand de Meeûs, the first Belgian governor of the Société Générale, the finance company that helped finance the expansion of the Belgian economy after 1830 by extensive direct investment in industry. In 1855, Ferdinand de Meeûs could look back on a distinguished career. ${ }^{22}$ Thanks to the fortune his father François-Joseph Meeûs (1765-

18 Société civile du crédit de la charité. Rapports lus à l'Assemblée générale des actionnaires, le 5 février 1857 (Brussels: J. Delfosse, 1857), 2.

19 Le Crédit de œuvres ouvrières et de la charité a.s.b.l. 1855-1955 (Brussels: s.n., 1955), 18.

20 Cited in De Haerne, Tableau, 82-83.

21 Jean-Joseph Thonissen, Vie du Comte Ferdinand de Meeus (Leuven: Ch. Peeters et Cie, 1863), 157; Désiré P.A. De Haerne, "Rapport sur la charité chrétienne en Belgique," Assemblée générale des catholiques en Belgique. Première session à Malines 18-22 août 1863, vol II, Compte-rendu des sections - Annexes (Brussels: H. Goemaere, 1864), 332; "Société civile du Crédit de la charité en Belgique,” Revue Générale, vol. VI, 3me année (Brussels: Comptoir universel d'imprimerie et de librairie Victor Devaux et Cie/Paris: C. Billet/'s Hertogenbosch: W. Van Gulick, 1867), 550; Société civile du crédit de la charité. Rapports lus à l'Assemblée générale des actionnaires, le 6 mars 1876 (Brussels: Louis Despret-Poliart, 1876), 6.

22 For biographical information, see: Poplimont, La Belgique, 179-240; Thonissen, Vie du Comte; "Le comte Ferdinand Philippe de Meeûs," in Ed. Terwecoren, Collection de précis histor- 
1821) had made in trade, the family became one of the leading families in Brussels. ${ }^{23}$ During French rule, Napoleon appointed François-Joseph Meeûs as president of the General Council of the Department of the Dyle. In the heyday of the United Kingdom of the Netherlands, the Catholic liberal François-Joseph was a member of the House of Representatives of the States General. ${ }^{24}$ When in August 1830 the unrest that would eventually lead to the the secession of the southern provinces and the establishment of the Kingdom of Belgium commenced, Ferdinand resolutely chose the side of the insurgents. Given his background as a banker and considering his firm commitment to the cause of the revolution, it was hardly surprising that the Provisional Government of Belgium nominated him, despite being only 32 years of age, as the first Belgian governor of the Société Générale. At the same time, Ferdinand was elected as a representative in the National Congress as well. From 1832 to 1845, he continued to represent Brussels in parliament. De Meeûs, a moderate liberal on the political level with a strong Catholic belief, fully supported the unionist policy and rejected the growing liberal discontent with these bargaining policies. In 1845 he was not re-elected. ${ }^{25} \mathrm{He}$ guided the Société Générale through the troubled first years. ${ }^{26}$ De Meeûs managed to transform the Société Générale into a mixed bank that fully invested and participated in the infrastructural and industrial development of the

iques, mélanges littéraires et scientifiques, Xe année (Brussels: J. Vandereydt, 1861), 334-344; Julie Laureyssens, “de Meeûs, Ferdinand," Nouvelle Biographie nationale, vol. 4 (Brussels: Académie royale des sciences, lettres et des beaux-arts de Belgique, 1997), 114-118; Herman Van der Wee and Monique Verbreyt, De Generale Bank 1822-1997. Een permanente uitdaging (Tielt: Lannoo, 1997), 35-36; Helena Taelman, "Prosopografische studie van de leden van de beheerraad van de Société Générale in de periode 1830 -1848” (Master’s thesis, University of Ghent, 2006), xiii-xiv.

23 On the family history, see: Jean-Louis Van Belle, Meeûs à de Meeûs: Bruxelles - la foi - le feu (Braine-le-Château: La taille d'Aulme, 1997) and the website of the Association Familiale d'Argenteuil (www.demeeus.org).

24 Herman Theodoor Colenbrander, Gedenkstukken der Algemeene Geschiedenis van Nederland van 1795 tot 1840. Achtste deel. Regeering van Willem I, 1815-1825. Tweede stuk ('s Gravenhage: Martinus Nijhoff, 1915), 549-550.

25 Michel Magits, "De socio-politieke samenstelling van de Volksraad (10 november 1830-21 juli 1831)," Belgisch Tijdschrift voor Nieuwste Geschiedenis 12, no. 3 (1981): 604; José Douxchamps, Présence nobiliaire au parlement belge (1830-1970). Notes généalogiques (WépionNamur: José Douxchamps, 2003), 83; Thonissen, Vie du Comte, 107.

26 Gita Deneckere, Leopold I. De eerste koning van Europa (Antwerp: De Bezige Bij, 2012): 391393; Els Witte, “Wijzigingen in de Belgische elite in 1830. Een voorlopige verkenning," BMGN Low Countries Historical Review 94, no. 22 (1979): 239-240. 
young state. ${ }^{27}$ He was strongly involved in the establishment of joint-stock companies. Ferdinand de Meeûs sat on the governing boards of many enterprises, as (honorary) chairman, director or administrator. ${ }^{28}$ He succeeded in establishing an impressive network. In 1836 King Leopold I bestowed on him the title of Count. ${ }^{29}$ In the meantime, de Meeûs had purchased a domain in Ohain near the Sonian Forest and built the castle of Argenteuil. ${ }^{30}$ With his Sociéte Civile pour l'Agrandissement et l'Embellissement de la Capitale de la Belgique, he ensured the development of the exclusive and elitist Leopold Quarter in Brussels. ${ }^{31}$

Throughout his life, Ferdinand de Meeûs was committed to different forms of charity. In 1822, the 24 year-old Ferdinand visited destitute families in the Brussels parish of St. Michael and St. Gudula for the Bureau de Bienfaisance ('Social Welfare Council'). ${ }^{32}$ In 1832, after his nomination as the governor of the Société Générale, he joined the board of directors of the Refuge des Vieillards des Ursulines in Brussels. His father had already held that position from 1809 until his death in $1821 .^{33}$ Ferdinand de Meeûs proved himself an active benefactor, both in the surroundings of the domain of Argenteuil as in the capital. ${ }^{34}$ He supported, among others, the alms-house of the Petites Soeurs des Pauvres, the institutions of the Filles de la Charité de Saint-Vincent-de-Paul, the works of the Enfance Catholique and the congregation of Saint Francis Xavier. ${ }^{35}$ He also patronised the

27 Van der Wee and Verbreyt, De Generale Bank, 39-49. See also: Julie M. Laureyssens, "Financial Innovation and Regulation. The Société Générale and the Belgian State after Independence (1830 - 1850)," Belgisch Tijdschrift voor Filologie en Geschiedenis 20, no 1-2 (1989): 223-250, and part 2 in Belgisch Tijdschrift voor Filologie en Geschiedenis 23, no 1-2 (1992): 61-89.

28 Samuel Tilman counted 22 mandates. See Samuel Tilman, Les grands banquiers belges, 1830-1935. Portrait collectif d'une élite (Mémoire de la Classe des Lettres. Collection in- $8^{\circ}$, 3e série, vol. XXXIX) (Brussels: Académie royale de Belgique, 2006), 23, 25. Even more records can be found in Louis-François-Bernard Trioen, Collection des statuts de toutes les sociétés anonymes et en commandité par actions de la Belgique, vol. 2. (Brussels: Chez l'auteur, 1839); Idem, Collection des statuts de toutes les sociétés anonymes et en commandité par actions de la Belgique (Brussels: Société belge de librarie, 1841); E. Van Damme, Manuel du Financier, des opérations en fonds publics et des sociétés par actions en Belgique. 1858-1859 (Ghent: D. Verhulst, 1859).

29 Poplimont, La Belgique, 161-162; Luc Duerloo and Paul Janssens, Wapenboek van de Belgische adel van de 15de tot de 20ste eeuw, vol. F-M (Brussels: Gemeentekrediet, 1992), 729.

30 Eric Meuwissen, Argenteuil, Le domaine “des” Rois (Ohain-Lasne: Éditions de la Page, 2005), $9-34$.

31 Frédéric Leroy, “Quand l'aristocratie et la grande bourgeoisie habitaient le quartier Léopold,” Belgisch Tijdschrift voor Filologie en Geschiedenis 88, no 2 (2010): 520.

32 Tilman, Les grands banquiers, 191.

33 Ibidem, 181-182.

34 See also: Thonissen, Vie du Comte, 158-163.

35 Poplimont, La Belgique, 237. 


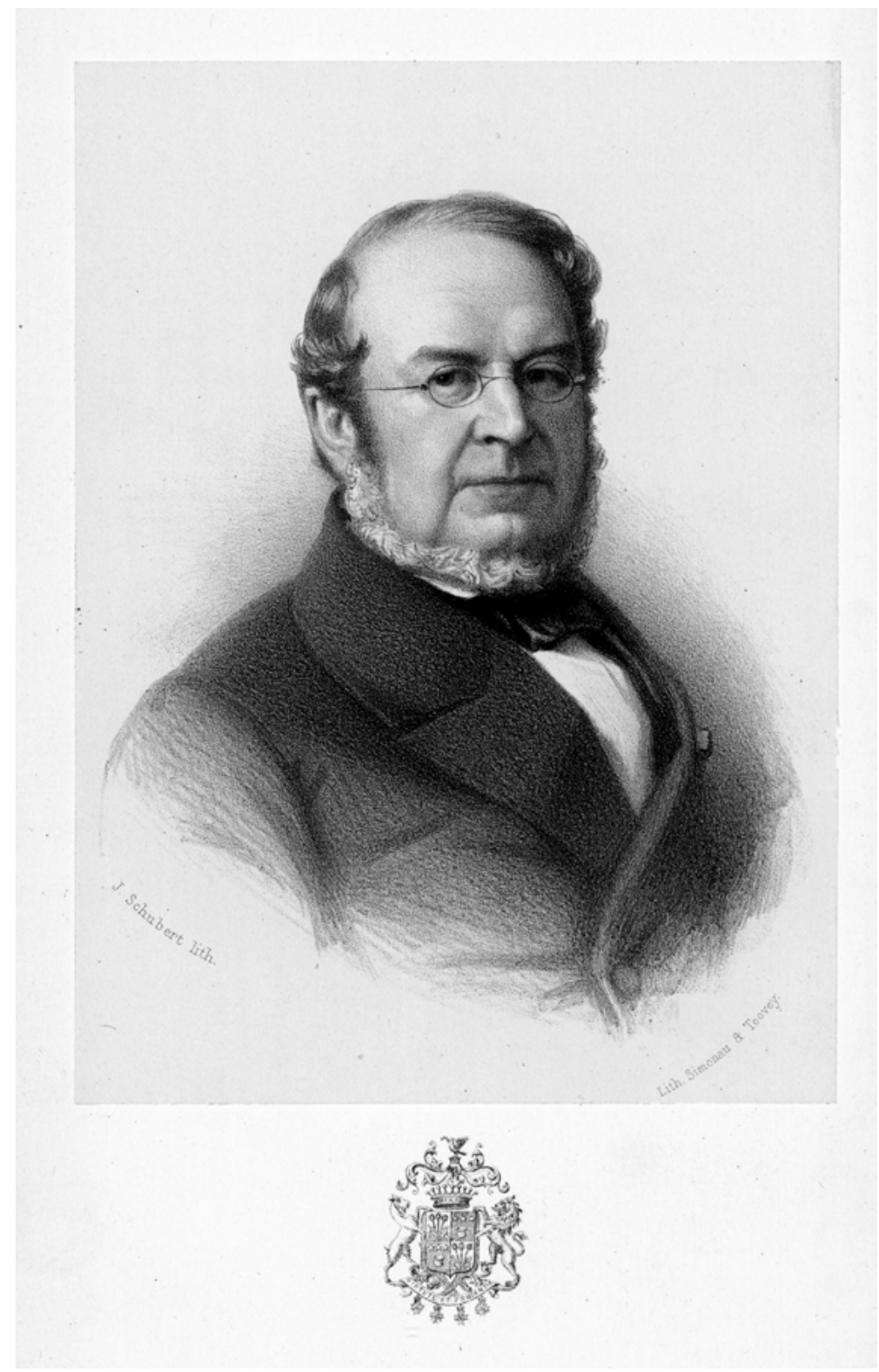

Fig. 4.1: Ferdinand de Meeûs (1798-1861), lithograph of J. Schubert in Jean-Joseph Thonissen, Vie du Comte Ferdinand de Meeus (1863). 
institute of the Dames de l'Adoration Perpétuelle du Très Saint-Sacrement, founded by his oldest daughter Anna (1823-1904). ${ }^{36}$

\section{Education for working-class children in industrial regions}

For some considerable time, long before the formation of the Société Civile du Crédit de la Charité in 1855, Ferdinand de Meeûs showed an interest in the fate of working-class families. In this, he pursued a dual strategy. On the one hand, he used his position as governor of the Société Générale to add a dimension of social welfare to the bank's investment policy. In 1840, for example, he was the driving force behind the creation of the Caisse de Prévoyance en faveur des Mineurs de l'Arrondissement de Mons. ${ }^{37}$ Financed by the administrators of industrial enterprises in the Borinage, the fund took care of the pensions of miners who were unable to work any longer, or delivered social benefits to widows and orphans of miners who were killed in accidents. In addition, the Caisse also intended to establish and support schools and offer free education. De Meeûs arranged that the Société Générale pour favoriser l'Industrie Nationale, the Société des Capitalistes Réunis dans un But de Mutualité Industrielle and the Société de Commerce de Bruxelles donated at least $5000 \mathrm{fr}$ each year to the fund for promoting education for working-class children. ${ }^{38}$ These contributions were used for

36 Martine Paret and Paul Wynants, "La noblesse belge dans les ordres religieux et les congrégations, 1801-1960,” Belgisch Tijdschrift voor Nieuwste Geschiedenis 30, no 3 - 4 (2000): 514; Annelies Hemelsoet "Liefdadigheid als roeping van een dame: Het sociaal engagement van de adellijke vrouw in het $19^{\mathrm{de}}$-eeuwse Gent (1845-1880)" (Master's thesis, University of Ghent, 2002), 120 -123; Daniel Bockstal, "La chapelle funéraire d’Anna de Meeûs à Watermael," Chroniques de Watermael-Boitfort, no 10 (2010): 8-14. Anna de Meeûs is one of the central characters in the doctoral dissertation " 'Too robust to be saint'. Female congregation founders in 19th-century Belgium: double-voiced agency, religious entrepreneurship and gender tension”, defended by Kristien Suenens on 30 October 2018 at the KU Leuven.

37 Thonissen, Vie du Comte, 141-142; Poplimont, La Belgique, 235.

38 Art. $3,5^{\circ}$, of the "Arrêté royal qui approuve les statuts de la caisse de prévoyance en faveur des ouvriers mineurs de l'arrondissement de Mons, province de Hainaut," Pasinomie, Troisième série, Tome dixième (Brussels: Société typographique belge, 1840), 560 - 563; Auguste Visschers, De l'état actuel et de l'avenir des caisses de prévoyance en faveur des ouvriers mineurs en Belgique (Brussels: B.J. Vandooren, 1847), 15, 29. In 1842, the Welfare Fund of Mons, with 31 affiliated enterprises, spent $8.250 \mathrm{fr}$ (13,30\% of the global expenses) on elementary education for $3004 \mathrm{pu}$ pils. For more numbers, see: Ibidem, 16, 20, 29. 
evening classes. Sunday schools proved to be less successful, except during winter. ${ }^{39}$ By 1860, 7703 children received free education thanks to this initiative. ${ }^{40}$

On the other hand, de Meeûs also did not hesitate to use his personal fortune and make significant donations to support the education of workingclass children. ${ }^{41}$ At first, he did so anonymously and wanted to keep his contributions a secret, even from his own family. ${ }^{42}$ In 1850, he travelled to Paris to meet the Superior General of the Frères des Écoles Chrétiennes ('Brothers of the Christian Schools'). At the congregation's headquarters, they arranged to scout for suitable locations in the Borinage, Charleroi and Châtelet. Thanks to his donations, the Brothers could start schools in Jemappes (1851), a suburb of Charlerloi (1851), Boussu (1852), Châtelet (1853), La Bouverie (1854), Châtelineau, and Dour (1855). Additionally, Ferdinand de Meeûs also funded the expansion of existing schools (for example in Frameries and Charleroi) of the Brothers, as well as the establishment of several adult schools. ${ }^{43}$

De Meeûs also approached business leaders from a variety of industrial enterprises to ask for additional support. This was by no means surprising, as de Meeûs was connected to many joint-stock companies through the Société Générale. Nevertheless, he soon realised that this formula would not last. The replacement of managers in these firms meant uncertainty about commitment in the long run. This is why he started looking for a more structurally sound and permanent solution for the funding of schools. Furthermore, he also wanted to give the project a larger scope. The establishment of the Société Civile du Crédit de la Charité would offer a solution.

\section{A formula for structural support}

The Société Civile du Crédit de la Charité pursued its own philosophy. In principle, the association did not intervene in the acquisition, rent, foundation or the set-up costs of schools. It argued that local benefactors were better placed to

39 Visschers, De l'état actuel, 29-31.

40 Thonissen, Vie du Comte, 143.

41 In 1855, he donated 14.281 fr. to the Frères des Écoles Chrétiennes in Belgium. See Félix Hutin, L'Institut des Frères des Écoles Chrétiennes en Belgique, vol. II, Les établissements des Frères sous le règne de la liberté constitutionnelle et sous la loi du 23 septembre 1842 de 1831 au 1er juillet 1879 (Namur/Aalst: Procure des Frères/Temse: Duculot-Roulin, 1912), 69.

42 The truth on these donations came out when the Brothers of the Christian Schools notified the family after his death. See: Thonissen, Vie du Comte, 144-145; Hutin, L'Institut, 67-68. 43 Thonissen, Vie du Comte, 146-147. 
judge whether the establishment of schools was appropriate. The majority of initiatives succeeded in acquiring start-up financing. However, this benevolence did not always last. ${ }^{44}$ After a first wave of enthusiasm, they faced financial troubles. This is where the Société came into the picture..$^{45}$ To prevent the downsizing or even discontinuation of educational activities, the society intervened and granted schools an annual allowance. If the institution planned further expansion, the subsidy could be raised.

The initiators of the plan left no room for doubt about their aims. With the organisation of Christian education, they wanted to counter increasing pauperism. ${ }^{46}$ Just like so many contemporaries, they ascribed poverty to a lack of proper upbringing. This explained, in their view, why workers squandered their hardearned income so inconsiderately on alcohol or in pubs..$^{47}$ Moreover, investing in education could help preserve social harmony..$^{48}$ At the same time, they also considered the idea of selecting the better students and helping them, by means of a scholarship of 300 to $400 \mathrm{fr}$, to go to college. That way, they could develop into reliable supervisors, who would one day take the lead on the factories' work floors. ${ }^{49}$

The formula of de Meeûs tried to overcome one of the main problems private associations faced. The law did not give them legal recognition, which was necessary to ensure continuity and stability in management (see above). ${ }^{50}$ By estab-

44 See also: Heyrman, "Bedrijfscultuur," 300-301.

45 Société civile du crédit de la charité. Rapports lus à l'Assemblée générale des actionnaires, le 5 février 1857 (Brussels: J. Delfosse, 1857), 5.

46 L'Économiste Belge argued that distributing relief was counterproductive and perpetuated poverty. The only way to tackle the root cause of the problem was to invest in prevention ("institutions de prévoyance"). See: "Societé du crédit de la charité," L'Économiste Belge. Journal des réformes économiques et administratives 2, no. 5 (5 March 1856): 3-4.

47 As pointed out by the administrative commission of the Welfare Fund of Mons: "We observe among a large number of labourers that the absence of religious principles, the lack of order, licentiousness, and the neglect of family relations go hand in hand with the lack of education. One does not have to look further than the abuse in the cabaret to find the cause of the small amount of pupils who go to Sunday schools and evening courses”, cited in Édouard Ducpétiaux, De l'association dans ses rapports avec l'amélioration du sort de la classe ouvrière (Brussels: Hayez, 1860), 27.

48 Paul Gérin, "Sociaal-katholieke verenigingen voor de arbeiders," in 150 jaar katholieke arbeidersbeweging in België (1789-1939), vol. 1, Het sociaal-katholicisme (1789-1886), ed. Servatius Herman Scholl (Brussels: S.V. De Arbeiderspers, 1963), 240-241.

49 Société civile du crédit de la charité. Rapports lus à l'Assemblée générale des actionnaires, le 7 mars 1859 (Brussels: J. Delfosse), 7.

50 "Société civile du crédit de la charité. Rapport lu à l’Assemblée générale des actionnaires, le 7 mars 1859,” Le Bien Public, March 13, 1859, 1. 
lishing a civil company, the Société wanted to bypass these regulations. ${ }^{51}$ Furthermore, the statutes permitted the board of directors to apply for a jointstock company status, if appropriate.

Within Catholic circles, quite a lot of people felt a certain aversion to investments or stock market speculation as a means to accumulate capital. In this case, however, the end justified the means. In 1859 the Catholic ultramontanist newspaper Le Bien Public included an editorial that stated that the acquisition of shares of the society was a nice heritage to leave one's children. ${ }^{52}$ In France, Catholics showed a bit more reticence. When Marie Gustave Baguenault de $\mathrm{Pu}$ chesse (1843-1922) presented the Société Civile du Crédit de la Charité before the Société d'Économie Charitable, two objections arose..$^{53}$ Some members questioned the prospect of establishing a civil company according to French law. More importantly, however, several speakers were afraid that the entanglement of making profit, speculation and charity would lead to distrust, criticism or accusations. In their eyes, the association faced the risk of becoming entangled in morally questionable practices.

Liberals responded sarcastically. The liberal journal Le Messager de Gand applauded the initiative, but expressed the hope that it would not go down the road of the empty promises the "hauts barons" of the Société Générale made twenty years earlier. After all, they had also recorded in their statutes the intention to found charitable institutions and alms-houses next to industrial enterprises. ${ }^{54}$ At the same time, the newspaper warned the board of directors. According to their statutes, not one of them could be held personally responsible for the potential debts of the association. Under such terms, the Société Civile du Crédit de la Charité misappropriated the prerogatives of a joint-stock company, although the conditions of the Commercial Code were not met. Without a proper legal base, the shareholders would have no guarantee at all of the reliability of their commitments.

The arrangement Ferdinand de Meeûs had set up matched his conviction that Catholic charities deserved every possible support. The means he accumulated were invested in stocks of industrial companies through his Société Générale which thus contributed just as much to economic development as it did to

51 With a formula of a "sociéte civile" or civil company the associates only risked the value of their capital investment. They could not be held liable for their management acts, unless they infringed the statutes. See: Van Damme, Manuel du Financier, 17.

52 Le Bien Public, May 3, 1859, 1.

53 "Société d'économie charitable," Le contemporain. Revue d'économie chrétienne, Nouvelle série, Septième année, vol. XI (Paris: Adrien Le Clere et Cie, 1866), 295-301.

54 "Société du crédit de la charité," Le Messager de Gand, January 15, 1856, 2-3. 
education. This in its turn advanced prosperity. ${ }^{55}$ The idea of financing the grants of the Société with the revenues from dividends entailed certain risks. If the stock portfolio was compiled in a balanced manner and the industries prospered, not only would the value of the stocks increase but also the revenues from dividends. However, economic fluctuations could get joint-stock companies into trouble, with obvious consequences for the distribution of profits. This is what happened at the beginning of the 1860s. ${ }^{56}$ From 1873 to 1874, the opposite occurred: business boomed to such an extent that the revenues of the Sociéte increased much more than anticipated. ${ }^{57}$

\section{A cautious financial policy}

Ensuring a healthy financial policy was no easy task. Commissioners pointed out deficits in the society's budget more than once. At some time in the future, the invested capital had to be paid back. Furthermore, the Société had made a commitment to pay interest of 2.5 per cent on the participation shares each year. There were also operational and administrative costs attached to the management of the capital. It was necessary to handle the influx of applications for support in a sufficiently selective way and adapt the commitments carefully to match the expected revenues. ${ }^{58}$ Diminishing the grants could have pernicious consequences for the continued existence of the schools. When in 1865 some of the institutions were threatened with closure, a number of shareholders put up the difference from their personal fortunes. ${ }^{59}$

In the first years of its existence, the Société seemed to prosper and grow. After some time, however, interest faded. The death of Ferdinand de Meeûs in 1861 was a serious blow. As the governor of the Société Générale, he had, without any doubt, a significant influence through his network of industrial entrepreneurs, bankers and venture capitalists. The expressions of interest and sympathy at the Catholic Congresses in Mechelen gave the Société a fresh breath. Adolphe Dechamps (1807-1875), a well-known Catholic representative, even expressed

55 “Société civile du crédit de la charité. Rapport lu à l'Assemblée générale des Actionnaires, le 5 mars 1860,” Journal de Bruxelles, March 10, 1860, 1.

56 Journal de Bruxelles, March 18, 1862, 1.

57 Société civile du crédit de la charité. Rapports lus à l'Assemblée générale des Actionnaires, le 5 mars 1877 (Ixelles: François Matthyssens, 1877), 5; Journal de Bruxelles, March 31, 1877, 1.

58 "Société civile du crédit de la charité. Rapport lu à l'Assemblée générale des Actionnaires, le 5 mars 1860," Journal de Bruxelles, March 10, 1860, 1.

59 Journal de Bruxelles, March 11, 1865, 1. 
the intention to augment the capital from 1 to 3 million fr by the end of the meetings. ${ }^{60}$ However, this desired financial stimulus never occurred. This caused some resentment within the board of directors. Some wondered aloud why the direct or indirect beneficiaries of the subsidies showed so little effort in attracting new shareholders or generous benefactors. At the same time, they alerted the Catholic community that new organisations were trying to draw young people away from the influence of the Church. ${ }^{61}$ The Société also pointed out that it had to deal with competition in its own ranks, with the foundation of the Ligue Nationale Belge ${ }^{62}$ and the École des Mines in Leuven. ${ }^{63}$ In 1879, for the first time in its existence, there was a fall in the civil company's capital. ${ }^{64}$ But the board of directors was not altogether worried about the future. In 1881, the board confidently stated that, even when all participation shares were claimed, all commitments to schools would be complied with. ${ }^{65}$

Table 1 and 2: Overview of the grants, and evolution of the capital, of the Société Civile du Crédit de la Charité, 1856-1880 (Source: annual financial reports of the society published between 1857 and 1881 or included in press articles)

\begin{tabular}{ll}
\hline Date & Total capital (in fr) \\
\hline 27.12 .1856 & 448900,92 \\
\hline 31.12 .1857 & 614840,98 \\
\hline 31.12 .1858 & 799508,87 \\
\hline
\end{tabular}

31.12. 1859

907476,55

60 Assemblée générale des catholiques en Belgique. Première session à Malines 18-22 août 1863, vol. II (Brussels: H. Goemaere, 1864), 79.

61 Société civile du crédit de la charité. Rapports lus à l'Assemblée générale des actionnaires, le 7 mars 1870 (Brussels : s.l., 1870), 6.

62 The Ligue Nationale Belge was established in 1872 as a reaction against the Paris Commune. This association merged into the Fédération des Sociétés Ouvrières Catholiques Belges in 1877. See: Jan De Maeyer, “De Belgische Volksbond en zijn antecedenten," in De christelijke arbeidersbeweging in België, vol. II (KADOC-Studies, 11), ed. Emmanuel Gerard (Leuven: Universitaire Pers, 1991), 24.

63 Société civile du crédit de la charité. Rapports lus à l'Assemblée générale des Actionnaires, le 3 mars 1873 (Brussels: E. Guyot, 1873), 10 -11. The École des Mines et des Arts et Manufactures was established in 1864 as part of the Faculty of Science at the University of Leuven, to train Catholic engineers.

64 Journal de Bruxelles, March 25, 1880, 2.

65 Société civile du crédit de la charité. Rapports lus à l'Assemblée générale des actionnaires, le 7 mars 1881 (Ixelles: François Matthyssens, 1881), 4. 
Table 1 and 2: Overview of the grants, and evolution of the capital, of the Société Civile du Crédit de la Charité, 1856-1880 (Source: annual financial reports of the society published between 1857 and 1881 or included in press articles) (Continued)

\begin{tabular}{ll}
\hline Date & Total capital (in fr) \\
\hline 31.12 .1860 & 1012078,28 \\
\hline 31.12 .1861 & 1036690,57 \\
\hline 31.12 .1862 & 1078359,92 \\
\hline 31.12 .1863 & 1104717,37 \\
\hline 31.12 .1864 & 1139708,63 \\
\hline 31.12 .1865 & 1012337,56 \\
\hline 31.12 .1866 & 1040953,52 \\
\hline 31.12 .1867 & 1066033,35 \\
\hline 31.12 .1868 & 1086031,68 \\
\hline 31.12 .1869 & 1090744,18 \\
\hline 31.12 .1870 & 1099494,48 \\
\hline 31.12 .1871 & 1105194,18 \\
\hline 31.12 .1872 & 1111324,18 \\
\hline 31.12 .1873 & 1340219,18 \\
\hline 31.12 .1874 & 1344044,12 \\
\hline 31.12 .1875 & 1349069,18 \\
\hline 31.12 .1876 & 1345206,68 \\
\hline 31.12 .1877 & 1405319,18 \\
\hline 31.12 .1878 & \\
\hline 31.12 .1879 & 1880 \\
\hline $312.18,68$ \\
\hline 30
\end{tabular}

\begin{tabular}{ll}
\hline Date & Grants disbursed (in fr) \\
\hline 31.12 .1856 & 26100 \\
\hline 31.12 .1857 & 23275 \\
\hline 31.12 .1858 & 33987,50
\end{tabular}


Continued

\begin{tabular}{|c|c|}
\hline Date & Grants disbursed (in fr) \\
\hline 31.12 .1859 & 45043,87 \\
\hline 31.12 .1860 & 51213,25 \\
\hline 31.12 .1861 & 56130,99 \\
\hline 31.12 .1862 & 54478,28 \\
\hline 31.12 .1863 & 56303,28 \\
\hline 31.12 .1864 & 56877,20 \\
\hline 31.12 .1865 & 57077,20 \\
\hline 31.12 .1866 & 58752,20 \\
\hline 31.12 .1867 & 58652,20 \\
\hline 31.12 .1868 & 60027,20 \\
\hline 31.12 .1869 & 60002,20 \\
\hline 31.12 .1870 & 59414,70 \\
\hline 31.12 .1871 & 58127,20 \\
\hline 31.12 .1872 & 58477,20 \\
\hline \multicolumn{2}{|l|}{31.12 .1873} \\
\hline 31.12 .1874 & 76337,26 \\
\hline 31.12 .1875 & 88938,30 \\
\hline 31.12 .1876 & 89450,80 \\
\hline 31.12 .1877 & 86612,80 \\
\hline 31.12 .1878 & 83871,99 \\
\hline 31.12 .1879 & 85496,99 \\
\hline 31.12 .1880 & 85821,99 \\
\hline
\end{tabular}

\section{Area of activity and coverage of the Société Civile du Crédit de la Charité}

The reports the board of directors submitted annually at the general meeting of the shareholders gave them a view of the pattern of subsidies granted by the association. In principle, these grants were financed solely through the revenues 
from investments. Until 1861, these revenues consistently permitted raising the level of funding. From 1861 to 1873, however, the board was obliged to contain the expenditure, until, after 1873, due to favourable economic conditions, a considerable increase in the subsidies became possible again. Grants amounted to 90,000 fr a year. This number was never to be surpassed as subsequently the Société saw its capital dwindle due to reimbursement of the participation shares.

We have at our disposal a detailed list of grants disbursed by the Société Civile du Crédit de la Charité for 15 years between 1856 and 1881. The majority of beneficiaries received a fixed yearly grant. This ranged from 50 fr (for Sunday schools) up to (a rather exceptional) 3600 fr for elementary schools. Grants of 300 to $600 \mathrm{fr}$ were the most common. These sums covered the annual cost of one teacher. ${ }^{66}$

The overview in table 3 shows that almost three quarter of the schools supported by the Société were elementary schools, with considerably more girls' schools than boys' schools. Various Sunday schools also got a boost. The category 'others' consists of all kinds of associations and institutions. Often, the grants for these institutions were disbursed on an occasional or temporary basis ${ }^{67}$, although, some kindergartens, hospitals, hospices and orphanages ${ }^{68}$ could count on a more structural form of support. The Société almost never deviated from its prevalent practices. Exceptions included support for the church and the schools of Argenteuil (Brabant) ${ }^{69}$, not surprisingly the residence of the de Meeûs family, and for the rent of schools in the Borinage. ${ }^{70}$

66 The Brothers of the Christian Schools counted 600 fr per brother as the annual remuneration (Hutin, L'Institut, II, 72). Given their vow of poverty and frugal way of life, this was not bad at all, but they financed the school supplies themselves, as confirmed by Cornelis Anton Van Bommel (1790 -1852), bishop of Liège, in a pastoral letter of 1831 (Ibidem, 103-104). This allocation was raised in Brussels in 1868 to $700 \mathrm{fr}$ (Ibidem, 459-462) and in Liège in 1875 to $750 \mathrm{fr}$, as a result of the rising cost of living (Ibidem, 404-405). In Nivelles, the allocation was raised in 1870 from 600 to $650 \mathrm{fr}$, and in 1872 to $700 \mathrm{fr}$ (Ibidem, 541).

67 Such as the lace workshop in Vilvoorde (Brabant), the Institut des Aveugles, Sourds \& Muets in Brussels, the orphanage Notre-Dame du Bon Pasteur in Namur, the Oeuvre des Forains in Brussels, patronage associations for young workers in Feluy (Hainaut), some parishes in Liège, the Patronage des Apprentis in Nivelles (Brabant), the Sociéte de St-François-Régis in Brussels (Brabant) and Mons (Hainaut), and the Société de St-Vincent-de-Paul in Kortemark (West Flanders). 68 In particular the kindergarten in Gosselies, Pâturages and Soignies (Hainaut), the hospitals in Frameries and Frasnes (Hainaut), the hospices in Jemappes and Templeuve (Hainaut), the girls' orphanages in Brugelette (Hainaut) and Durbuy (Luxemburg).

69 With a subsidy of $8112,5 \mathrm{fr}$ in 1875 and grants of $8450 \mathrm{fr}$ in the following years. See: Société civile du crédit de la charité. Rapports lus à l'Assemblée générale des actionnaires, le 6 mars 1876 (Brussels: Louis Despret-Poliart, 1876); Société civile du crédit de la charité. Rapports lus à l'Assemblée générale des actionnaires, le 5 mars 1877 (Ixelles: François Matthyssens, 1877); Société 
Table 3: Overview of the number of institutions per province subsidised by the Société, 18561881 (Source: annual financial reports of the society published between 1857 and 1881 or included in press articles)

\begin{tabular}{llllll}
\hline & Boys' school & Girls' school & Sunday school & Others & Total \\
Antwerp & 1 & 4 & 0 & & 5 \\
Brabant & 12 & 15 & 2 & 11 & 40 \\
West Flanders & 0 & 1 & 0 & 1 & 2 \\
East Flanders & 0 & 0 & 0 & 0 & 0 \\
Hainaut & 29 & 25 & 8 & 14 & 76 \\
Liège & 2 & 16 & 0 & 3 & 21 \\
Limburg & 0 & 1 & 0 & 0 & 1 \\
Luxemburg & 1 & 2 & 0 & 1 & 4 \\
Namur & 4 & 8 & 0 & 2 & 14 \\
Total & 49 & 72 & 10 & 32 & 163 \\
\hline
\end{tabular}

From the start, the Société had stated that its main working area would be the mining regions of Hainaut and Liège. This made sense since the board was convinced that it was in industrial regions that the need for a religious education was most essential, even though the association did not want to ignore needs elsewhere. Brussels especially merited particular consideration. ${ }^{71}$ The figures in table 3 prove that the Société complied with its intentions. Almost half of all endowed associations and institutions were indeed located in Hainaut, a quarter in Brussels. The Flemish provinces, East and West Flanders in particular, were ignored almost entirely. ${ }^{72}$ The annual report of 1875 summarised the geographical coverage following ecclesiastical demarcations: 33 institutions in the

civile du crédit de la charité. Rapports lus à l'Assemblée générale des actionnaires, le 4 mars 1878 (Ixelles: François Matthyssens, 1878); Société civile du crédit de la charité. Rapports lus à l'Assemblée générale des actionnaires, le 1 mars 1880 (Ixelles: François Matthyssens, 1880) and Société civile du crédit de la charité. Rapports lus à l'Assemblée générale des actionnaires, le 7 mars 1881 (Ixelles: François Matthyssens, 1881).

70 With a subsidy of $2301 \mathrm{fr}$ in 1863 and $1250 \mathrm{fr}$ the following years. See : "Rapport présenté par M. le comte Eugène de Meeûs, au nom de l'administration de la Société civile du Crédit de la Charité," Assemblée générale des catholiques en Belgique. Troisième session à Malines, 2-7 septembre 1867 (Brussels: Comptoir universel d'imprimerie et de librairie Victor Devaux et Cie, 1868), 264-269; Journal de Bruxelles, March 18, 1867, 1; Société civile du crédit de la charité. Rapports lus à l'Assemblée générale des actionnaires, le 2 mars 1868 (Brussels: s.n., 1868).

71 See, for example: Société civile du crédit de la charité. Rapports lus à l'Assemblée générale des actionnaires, le 2 mars 1868 (Brussels: s.n., 1868), 10.

72 De Haerne, "Rapport," 332-333. 
diocese of Mechelen, 55 in the diocese of Tournai, 10 in the diocese of Namur, 17 in the diocese of Liège, and 1 in the diocese of Bruges. ${ }^{73}$

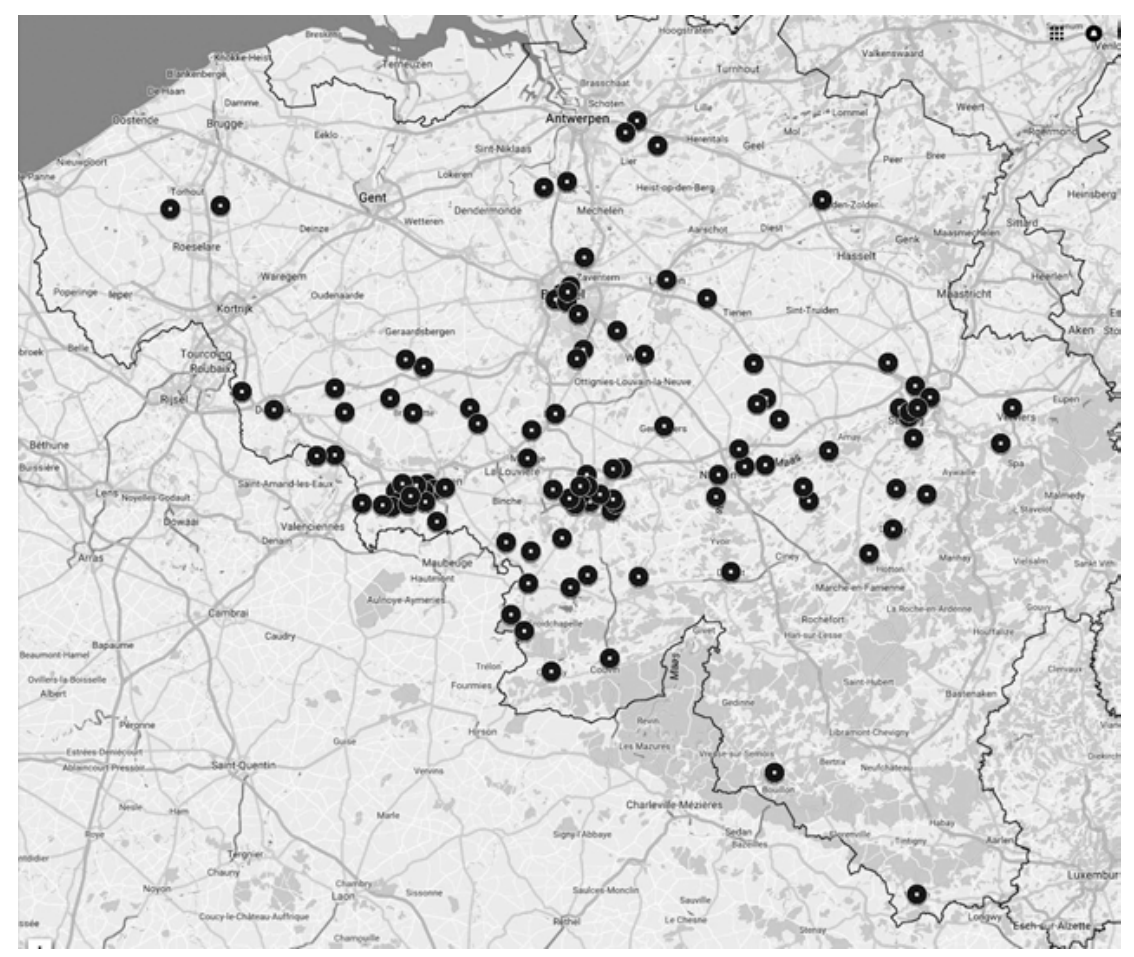

Map: Institutions supported by the Société Civile du Crédit de la Charité, 1856-1881

\section{The run-up to the school war}

Count Eugène de Meeûs (1834-1915) ${ }^{74}$, who succeeded his father in 1861, managed to draw attention to his organisation at the Catholic congresses in Mechelen (1863, 1867, 1867), meetings inspired by the German Katholikentage. He did this

73 Société civile du crédit de la charité. Rapports lus à l'Assemblée générale des actionnaires, le 6 mars 1876 (Brussels: Louis Despret-Poliart, 1876), 6.

74 Eugène François Joseph Ferdinand was married to Marie Charlotte Célestine de Couédic de Kergoaler. 
by outlining the intentions and practices of the Societé. ${ }^{75}$ The Count was also a member of the bureau of the second section, which discussed the Oeuvres de Charité ('charitable work'). The bureau had the social Catholic lawyer and economist Charles Périn (1815-1905) as its chairman. Eugène de Meeûs was appointed secretary. ${ }^{76}$ Little wonder, then, that the resolutions of the first conference cited the Société Civile du Crédit de la Charité as a model that could inspire and support other Catholic charitable organisations. ${ }^{77}$ The French social Catholic Armand de Melun (1807-1877), the co-founder of the Société d'Économie Charitable, saw the Société Civile du Crédit de la Charité as an example for French Catholics. ${ }^{78}$ The formula could also be an inspiration elsewhere in Belgium. The superior of a well-known Catholic school in Roeselare argued unequivocally in favour of the establishment of a Crédit de l'Enseignement Catholique to counter the appeal of public secondary schools. ${ }^{79}$ The idea to implement the principles of the Société Civile du Crédit de la Charité in other charities and institutions, both at home and abroad, was also discussed in other sections of the conferences. ${ }^{80}$

Catholics complained about the secularising educational policy of liberal governments and the application of the primary education law of $1842 .{ }^{81}$ This resulted in the accusation that the liberal policy-makers maintained a political agenda to prevent Catholic schools from acquiring a legal status and therefore become entitled to government subsidies. ${ }^{82}$ There were various reasons for distrust and animosity: the hardline policy of the liberal Minister of Justice François

75 This happened already at the first congress in August 1863. See Assemblée générale des catholiques en Belgique. Première session à Malines 18-22 août 1863, vol. II (Brussels: H. Goemaere, 1864), $60-61$.

76 Assemblée générale des catholiques en Belgique. Première session à Malines 18-22 août 1863, vol. I (Brussels: H. Goemaere, 1864), 6.

77 Assemblée générale des catholiques, Première session, vol. I, 469.

78 Armand De Melun, "Rapport sur les Oeuvres de Charité chrétienne et leur extension," Assemblée générale des catholiques, Première session, vol. I, 122; Assemblée générale des catholiques en Belgique. Deuxième session à Malines, 29 août-3 septembre 1864, vol. II (Brussels: Comptoir universel d'imprimerie et de librairie V. Devaux et Cie/Paris: Régis Ruffet et Cie, 1865), 164. 79 Assemblée générale des catholiques, Première session, vol. II, 97, 98-99, 112.

80 Assemblée générale des catholiques en Belgique. Troisième session à Malines, 2-7 septembre 1867 (Brussels: Comptoir universel d'imprimerie et de librairie Victor Devaux et Cie, 1868), 161. See also resolution VIII of the first section ('Oeuvres religieuses') and resolution VII, $1^{\circ}$ of the third section ('Education et Instruction chrétienne'), in Ibid, 326, 330.

81 Jan De Maeyer, De rode baron. Arthur Verhaegen 1847-1917 (KADOC-Studies, 18) (Leuven: Universitaire Pers, 1994), 67.

82 See, for example, the intervention of Adolphe Dechamps: Assemblée générale des catholiques, Première session, vol. II, 79-82; Société civile du crédit de la charité. Rapports lus à l'Assemblée générale des actionnaires, le 2 mars 1868 (Brussels: s.n., 1868), 9. 
de Haussy (1789-1869) between 1847 and 1850 towards charitable foundations, the particular polarising dispute over Monastic Law (1857-1859), or the debate on educational funds and scholarships (1862). Catholics perceived all these as liberal attempts to restrain or even impede the funding of Catholic education as much as possible. ${ }^{83}$ The publication of the papal encyclical Quanta Cura and the annex, the Syllabus Errorum (1864), caused emotions to run even higher. $^{84}$

The social deepening of the liberal-clerical conflict led to the use of strikingly aggressive language regarding the Société. In 1864, several Catholic newspapers published a reaction by the Bishop of Bruges, Jean-Baptiste Malou (1809-1864), to the annual report of the Société Civile du Crédit de la Charité which Eugène de Meeûs had presented at the second Mechelen conference. The Church leader expressed a wish that the numerous schools that received support from the Société serve in the battle against the "anti-Christian sects" that threatened civil society. ${ }^{85}$ When covering the financial report of the Société of 1865, the Catholic newspaper Journal de Bruxelles stated that rationalists and freethinkers had declared a "war against religious education". Catholic papers complained that the tax revenues of Catholics were used in cities to finance public schools. The campaign seemed especially directed at the Brothers of the Christian Schools, as they were removed from municipal schools everywhere. ${ }^{86}$

Catholics became increasingly aware that the anticlerical side had started organising itself in order to obtain private fundraising for secularised schools. From 1854 onwards, Masonic lodges publicly promoted public education and commented on the question of compulsory education. ${ }^{87}$ The opponent par excellence became the Ligue de l'Enseignement, launched in $1864 .^{88}$ In 1867 , this association started collecting money from sympathisers. In 1872, this initiative, Deni-

83 Gubin and Nandrin, "Het liberale en burgerlijke België 1846-1878," 286-301; Witte, "The Battle," 109-113.

84 Vanderstraeten, "Religious Congregations," 140.

85 "Société civile du crédit de la charité," Journal de Bruxelles, March 12, 1864, 2; "Société du crédit de la charité,” Le Bien Public, March 14, 1864, 1.

86 "Société du crédit de la charité," Journal de Bruxelles, March 12, 1866, 1; "Société du crédit de la charité," Le Bien Public, March 13, 1866, 1.

87 Pierre Verhaegen, La lutte scolaire en Belgique (Ghent: A. Siffer, 1906), 31-35; Lory, Libéralisme, I, 267-301. See also : Jeffrey Tyssens and Hendrik Van Daele, "Orde, zorg en spaarzaamheid. Vrijmetselarij en onderwijs," in Van wijsheid met vreugd gepaard. Twee eeuwen vrijmetselarij in Gent en Antwerpen, ed. Jeffrey Tyssens (Brussels: Marot/Ghent: Tijdsbeeld, 2003), 143147.

88 For the history of this organisation, see chapter 5 in this volume. 
er de l'Instruction, was transformed into an organisation: the Denier des Écoles. ${ }^{89}$ Despite the scepticism in liberal circles, fundraising associations emerged in numerous cities and municipalities during the 1870s when Catholic governments ruled the country. In 1875 the organisations in Brussels united in a Fédération du Denier des Écoles. Many other liberal fundraising associations in the provinces soon joined. Together they succeed in collecting nearly 83,000 fr in 1875, over $175,000 \mathrm{fr}$ in 1876, more than 212,000 fr in 1877, and almost 234,000 fr in $1878 .^{90}$ With these funds between 1876 and 1879 they supported schools in Aalst, Ath, Mons, Bruges, Brussels, Dendermonde, Ellezelles, Frameries, Kortrijk, Lokeren, Ninove and Oudenaarde. The Fédération focused particularly on (secondary) girls' education, bilingual training and modern-day pedagogy. ${ }^{91}$ Their reports mentioned that more than 85,000 fr on grants were disbursed in 1875-1876, over 96,000 fr in 1877 and almost 88,000 fr in 1878. The vast majority of these grants went to a model school for boys, founded by the Ligue de l'Enseignement, and a vocational school for girls in Brussels. ${ }^{92}$

A Catholic countermove was deemed more necessary than ever. ${ }^{93}$ However, launching Catholic fundraising organisations took some time. In Ghent, Alfons Siffer (1850 - 1941) and Guillaume Verspeyen (1837-1912) took the lead in October 1876 with the creation of the Katholieke Schoolpenning, under the aegis of the Commission Épiscopale des Écoles Chrétiennes de Gand (which had already been installed as early as 1858). ${ }^{94}$ The latter served as a means for collecting funds for

89 Lory, Libéralisme, I, 325-446. The name choice was seen as the liberal answer to the Catholic Peter's Pence. For a comprehensive history, see: Lory, Libéralisme, II, 521-585. See also: André Uyttebrouck, "Les grandes étapes d'une histoire de cent vingt-cinq années," Histoire de la Ligue de l'Enseignement et de l'Éducation permanente 1864-1989 (Brussels: Ligue de l'Enseignement, 1990), 11-21; "Fédération du 'Cercle des Collecteurs du Denier des écoles'," in Dictionnaire historique de la laïcité en Belgique, ed. Pol Delfosse (Brussels: Fondation Rationaliste/ Editions Luc Pire, 2005), 122-124.

90 Detailed numbers in Lory, Libéralisme, II, 540-541.

91 Ibid, 546-548.

92 Ibidem, 534; Baudouin Groessens, "Laïcité et l'enseignement primaire en Belgique 1830 1914. De l'affrontement au pluralisme” (PhD diss., Université Catholique de Louvain-la-Neuve, 2004), 173-183; Pol Delfosse and Marcel Paspesant, "De l'École Modèle de Bruxelles (18751879) à l'École Moderne de Barcelone (1901-1906)," Cahiers Bruxellois - Brusselse Cahiers 47, no 1 (2015): 56-73; Marianne de Vreese, "L'association pour l'enseignement professionnel des femmes et les débuts de l'école Bischoffsheim à Bruxelles, 1864-1868,” Belgisch Tijdschrift voor Nieuwste Geschiedenis 22, no 3-4 (1991): 625-655.

93 Journal de Bruxelles, April 10, 1873, 1.

94 Bruno Boulange, "L'établissement de l'enseignement primaire catholique à Liège sous l'épiscopat de Monseigneur Doutreloux (1879-1901)," Belgisch Tijdschrift voor Nieuwste Geschiedenis 17, no 3-4 (1986): 314-315; Heyrman, "Bedrijfscultuur," 308-309. 
the construction of schools. ${ }^{95}$ In December 1876 a Schoolpenning voor Katholiek Vlaamsch Onderwijs ('School Penning for Catholic Flemish Education') was founded in Antwerp. ${ }^{96}$ Subsequently, similar organisations followed elsewhere. ${ }^{97}$ At the beginning of 1879 several prominent Catholics developed a plan under the impetus of former Prime Minister Jules Malou (1810-1886), to launch a national organisation that would coordinate the Catholic counter-offensive. The bishops of Tournai (Edmond Dumont, 1828-1892) and Liège (Théodore de Montpellier, 1807-1879) opposed this. They felt that it would interfere with existing initiatives, such as the Commissions des Écoles des Frères de la Doctrine Chrétienne or the Société Civile du Crédit de la Charité. Moreover, and above all, they objected to it being presided over by laymen and assumed that that role should be reserved for the clergy. ${ }^{98}$ The associations presenting themselves as Katholieke Schoolpenningen ('Catholic School Pennies') met for the first time on 31 August 1879 in Dendermonde. Two years later, on 17 December 1882, the statutes were approved for a Fédération Belge des Deniers des Écoles Catholiques et Oeuvres Similaires. ${ }^{99}$

In the meantime, however, the context had changed. In 1878, the Liberals took office, and in June 1879, a new primary education bill was adopted. Each municipality was now obliged to maintain at least one public primary school. Parents could ask for religious studies in these schools, but these courses had to be taught outside regular hours. The Catholics saw the primary education bill as a declaration of war and reacted immediately with aggressive rhetoric and a massive mobilisation of resources. The bishops initiated a major campaign to found Catholic schools in as many municipalities as possible. ${ }^{100}$ The outbreak of the school war in 1879 also had consequences for the Société Civile du Crédit de la Charité. Initiatives such as the Catholic School Pennies attracted all the attention and proved successful fundraisers as they provided the necessary means to fund the building of new schools. Catholic publicist Pierre Verhaegen (1873-

95 De Maeyer, De rode baron, 155.

96 Inventaris van het archief Katholieke Schoolpenning Antwerpen (Inventarissen en repertoria, 2) (Leuven: KADOC, 1980).

97 Such as the Denier des Écoles Catholiques in Doornik, established on the 25 of February 1878 (Jean-Luc Soete, “La resistance catholique face à la loi Van Humbeeck dans l'arrondissement de Tournai (1878-1884),” Belgisch Tijdschrift voor Nieuwste Geschiedenis 11, no 1-2 (1980): 139140) or the Denier des Écoles Catholiques in the city of Liège, established on 24 March 1879 (Boulange, "L'établissement," 314). On Catholic School Pennies, see: Pierre Verhaegen, La lutte scolaire en Belgique (Ghent: A. Siffer, 1906), 117-123.

98 Boulange, "L'établissement," 310-314.

99 Ibidem, 315.

100 Witte, "The Battle," 118-120. 
1953) estimated that the investments for 1879 alone amounted to 40 million fr. With this money, 2064 schools were founded in one year. ${ }^{101}$ Since the Société Civile du Crédit de la Charité focused on providing structural support over the long term, it could not really benefit from this general mobilisation to build new Catholic schools. ${ }^{102}$ The board of the Société claimed that the association had been prepared for a long time for this open confrontation between Catholic schools and "schools without God". They believed society would be ready to guarantee the continued existence of these new schools when financial support was needed. The Société thus adhered to its original intention: "it does not suffice to create schools, it is necessary to assure their future and prosperity". ${ }^{103}$ The association continued the practice of issuing annual grants. Consequently, the Société receded into the background amid all the commotion surrounding the ideological conflict. Its modus operandi did not change. Year after year, the board of directors invited the shareholders on the general assembly to report on the results.

\section{Conclusion}

Our story ends with the school war of 1879-1884. By then, the confrontation between Catholics and liberals over education had escalated resulting in an aggressive Catholic offensive. The battle for the soul of the child remained ultimately a struggle for funds, something that should not be underestimated. Whether it was about the financing of autonomous (confessional or secularised) schools, or about subsidising public education or institutions authorised and inspected by the state, or whether it dealt with the mobilisation of funds in a network of kindred spirits, or with government investments, the dispute over education was a power struggle in which the financial dimension had both a binding and a polarising effect.

101 Verhaegen, La lutte scolaire, 123, 130. In 1870, Catholic publicist Prosper de Haulleville $(1830-1898)$ estimated the amount needed to cover all current expenses at approximately 5 million fr. Others presumed an amount of 7 or 8 million fr. According to de Haulleville, funding education could be viable, if in all large cities initiatives such as the Société Civile du Crédit de la Charité existed and cooperated. See Prosper De Haulleville, De l'enseignement primaire en Belgique (Brussels: Comptoir universel d'imprimerie et de librairie Victor Devaux et Cie, 1870), $327-331$.

102 Société civile du crédit de la charité. Rapports lus à l'Assemblée générale des actionnaires, le 1 mars 1880 (Ixelles: François Matthyssens, 1880), 4-5.

103 Journal de Bruxelles, March 25, 1880, 2. 
At the beginning of this chapter I observed that the financing of popular education, especially private initiatives, has up until now received very little attention. Many aspects deserve both in-depth and at-length research. The questions seem obvious: Who was involved? Can we reconstruct the flows of funds? How did public-private cooperation evolve? To what extent was free education guaranteed? What was the real impact? Were there differences between cities and the countryside, between industrial and rural regions? What was the part played by public relief, the parish clergy, the religious congregations, the local elite, or entrepreneurs? What was the public's view of all of this?

In this chapter, I focused on the ideas and actions of Ferdinand de Meeûs and his Société Civile du Crédit de la Charité. By using his extensive network of entrepreneurs and investors, and his expertise as a banker, de Meeûs developed an original funding mechanism. To raise money he did not opt for conventional fundraising, such as foundations or collections, but for a more 'modern' approach. By raising capital through the issuance of shares and investment in industrial developments, he sought to generate resources in the long term for investing in charities. People who believed in the cause did not have to give away their fortune. The only thing participants renounced was a part of the profit they would have received if they had chosen to invest (directly) on the stock market. The modest but guaranteed interest rates offered a certain return anyway. Although capital was secured for the next 20, 30 or 50 years, or for an indefinite period, it remained their property in the form of bonds. A healthy financial policy pursued by the Société assured reimbursement for them or their heirs. In the meantime, they not only facilitated economic prosperity but also the moral education of the working class. Even Catholics who were reluctant or sceptical about stock market speculation could hardly raise objections to this formula. In a period when emotions ran high regarding disputes over the role of religious institutions in organising charity and education, Ferdinand de Meeûs formulated a 'business-wise' approach to the question of funding charity.

The numbers prove the vital importance of Ferdinand de Meeûs' position and contacts for the success of the organisation. After his death, the accumulation of capital came virtually to a standstill. Catholic circles were not enthusiastic about purchasing shares, much to the board of directors' frustration. They inevitably had to more or less freeze their grants. Nevertheless, the son and successor of the founder, Eugène de Meeûs, made every effort to revive interest. At the Catholic congresses in Mechelen in the 1860s, he was met with general approval. The Société was hailed as a model and a source of inspiration. However, this propaganda did not cause a rush on the shares. Despite all the recommendations for it, the example was not emulated. 
The economic situation improved after 1873. Meanwhile, the context had changed drastically: it was the age of the School Pennies. Liberal as well as Catholic associations became engaged in a battle to gather as much financial support as possible for their own educational system. As a result, the Société Civile du Crédit de la Charité receded into the background. The Société made the choice not to invest in school buildings and equipment. The grants were meant to keep schools running, by contributing to staff and operational costs. While the School Pennies set up sections everywhere, organised themselves together in national federations and played their part in the school war (1879-1884), the Société continued its practice. That the Société never achieved national relevance can be explained by a combination of factors. First, it used a method which was unusual and exceptional in the world of charity. Banks and the stock market seemed far removed from the more traditional approach of charity. Second, the formula itself required a different set of skills from those needed for organising the receipt of gifts and donations. One had to be well informed in order to raise money and invest profitably. Third, the Société complemented other initiatives. It held on to a long-term perspective and left short-time investment programmes to occasional fundraising. Fourth, the organisation continued as a family business. The Société set its own course and showed no intentions of associating with, or integrating in, the Catholic organisational network. It presented its results and gained standing and respect for its aims and efforts while maintaining its independence.

Could an association such as the Société Civile du Crédit de la Charité make a real difference to popular education? The principles at least were clear: the organisation focused on industrial growth poles and sought to educate workingclass children in confessional schools. This served a broader societal goal of moralising workers and tackling pauperism. At the same time, it supplied the business enterprises in these regions with disciplined workers over the next generations. Moreover, the most promising pupils could be selected and trained to later assume responsibility on the factory floor. The amount the Société spent on annual grants was not negligible, but not spectacular either. They ensured the deployment of dozens of clerics who educated several thousand children each year, for the most part free of charge. In provinces such as Hainaut and Liège, this was not insignificant. For a congregation such as the Brothers of the Christian Schools, this support resulted in a reliable and sizeable source of income of more than $900,000 \mathrm{fr}$ over a period of 28 years. Compared to the overall amount of grant money delivered by the liberal Fédération du Denier des Écoles in 1875 to 1878, the efforts of the Société were within the same range. But compared to the investment of the Catholic School Pennies in the midst of the school war, the grants from the Société seemed rather modest. 
The Société Civile du Crédit de la Charité survived the school wars and continued working. On 24 July 1922, it was converted by the notary Victor Scheyven in Brussels into a non-profit association under the name Le Crédit des Oeuvres Ouvrières et de la Charité. ${ }^{104}$ Its aims remained the same: "to contribute to the establishment and maintenance of Christian schools and care institutions for the elderly and disabled people, especially in the mining regions in the provinces of Hainaut and Liège, and in Brussels”. In 2004, the statutes were amended and the name changed to Crédit des Oeuvres. ${ }^{105}$ To this day the board is still in the hands of the de Meeûs d'Argenteuil family.

104 Published in the Belgisch Staatsblad on 30 August 1922, no 573; Le Crédit de œuvres ouvrières et de la charité a.s.b.l. 1855-1955 (Brussels, 1955), 19-20.

105 Published in the Annexes of the Belgisch Staatsblad of 9 March 2005. 